COMPARATIVE STUDY OF HYBRID FIBER CEMENTITIOUS COMPOSITES

\author{
Maria Idrees \\ University of Engineering and Technology Lahore, Pakistan \\ E-mail: mariaidrees@uet.edu.pk \\ Farah Nawaz Qureshi \\ University of Engineering and Technology Lahore, Pakistan \\ E-mail: fnq2105@gmail.com \\ Kafeel Ahmad \\ University of Central Punjab, Pakistan \\ E-mail: kafeel.ahmed@ucp.edu.pk \\ Sajjad Mubin \\ University of Engineering and Technology Lahore, Pakistan \\ E-mail: sajjadmubin@uet.edu.pk
}

Submission: 6/22/2019

Revision: 9/18/2019

Accept: 10/9/2019

\title{
ABSTRACT
}

Different types of fibers impart specific characteristics to concrete, including crack bridging, early age crack resistance, ductility, toughness, strength, and loss of workability. It seems that if these fibers are combined, then specific characteristics of each fiber may be imparted to concrete and the desired characteristics of the concrete composite may be achieved. Thus, this investigation has been conducted to study the properties of concrete composites composed of four different types of fibers used singly or in hybrid form. The effectiveness of hybrid fibers in cementitious composites to achieve better characteristics; strengths, toughness, workability, and cost, was investigated and compared. Composites made of carbon fiber, plain steel fiber, polypropylene fiber, and glass fiber and their hybrid combinations (2, 3 and 4 fibers mixed), at constant volume of fiber $1.25 \%$, along $4 \%$ styrene-butadiene rubber latex and 1.5\% superplasticizer, are prepared and tested. The composites are compared and investigated for their feasibility in terms of their properties and cost. 
DOI: 10.14807/ijmp.v11i3.1081

The comparison showed the suitability of some bi-hybrid composites, and incompatibility of tri-hybrid and tetra-hybrid composites in terms of effectiveness and feasibility.

Keywords: Hybrid Composites, Polymers, Material properties, Mechanical properties, Toughness.

\section{LIST OF NOTATIONS:}

C

Carbon Fiber

G

Glass Fiber

FRC $\quad$ Fiber Polymer Cementitious Composites

P Polypropylene Fiber

S Steel Fiber

SBR Styrene butadiene rubber latex

\section{INTRODUCTION}

The extensive research on fiber-based cementitious composites is being carried out to gain maximum benefits out of fibers at minimum cost. By optimizing them for maximum efficiency, their properties like the aspect ratio of fiber, the volume of fiber, shapes, and sizes of fibers were studied in the past. The research aims to study the effectiveness of hybrid fiber in cementitious composites to achieve better characteristics, i.e., strengths, toughness, and workability at the lower cost.

Plain concrete is brittle and has a low tensile strength and strain capacity. These shortcomings can be overcome by adding fibers and producing fiber cement composites (FRC). Fibers may or may not increase the strength depending upon their types, volume, aspect ratio, shapes, etc. however, they can bridge cracks and provide post cracking ductility. (BENTUR; MINDESS, 2006)

The initial cracking of concrete during the curing period can be effectively reduced by using organic synthetic fiber. The high strength fibers like steel and carbon can efficiently increase the tensile strength of concrete. However, the increase depends upon the bond strength between concrete and fiber. The durability of fiber reinforced concrete increases due to controlled cracking.

The main function of fibers in a cementitious material is to control the cracking by bridging the advancing crack. It results in an improvement in flexural toughness and other properties like impact strength and ductility (BADR; ASHOUR; PLATTEN, 2006). 
INDEPENDENT JOURNAL OF MANAGEMENT \& PRODUCTION (IJM\&P)

http://www.ijmp.jor.br

v. 11, n. 3, May-June 2020

ISSN: $2236-269 X$

DOI: 10.14807/ijmp.v11i3.1081

The problems associated with fiber incorporation are; loss of workability, difficulty in casting, high cost, and sometimes reduction in strength and durability due to the high volume of entrapped air.

The workability problem can be addressed by adding SBR latex in FRC. SBR latex in concrete increases the workability and reduces water ingress. It enhances the durability and improves the strength of concretes at 28 days. (SONI; JOSHI, 2014)

Additionally, bonding between fibers and matrix plays a vital role in determining the strength of concrete, durability, and energy absorption capacity. SBR provides excellent bonding characteristics to the matrix. (WANG; LACKNER; WANG, 2011)

G. N. Shete showed that SBR latex improves the internal structure of latex modified concrete at 28 days and hence reduces water absorption. SBR modified concrete has lower strength than conventional concrete at early ages, but it increases at 28 days. (SHETE, 2014)

Different fiber has different properties like color, texture, elongation capacity, strength parameters, resistance to chemicals and electrical conductivity, etc. and when added to concrete, they behave differently in the matrix. They transfer their properties to the concrete when added. Selection of fiber should be according to the building type or requirement of construction. Hybridization of fiber may be the most effective way to achieve cost-effective combination with high toughness and strength properties.

By adding optimum percentages of each fiber content, we may get the synergetic response in properties and highest strength to cost ratio as well. Hybridization of fibers may lead us towards a structure in which one type of fiber, which is stronger and tougher, improves the peak load value and ultimate strength, where the other type of fiber, which is more ductile, provides the improved toughness and strain capacity in the post-cracking phase. Steel fiber gives the highest toughness as compared to all other fibers, it gives pullout failure under flexural loading, but due to higher density of these fibers, electrical conductivity and magnetic fields associated with it, it may lead to hybridization with other high strength fiber like carbon fiber.

Hybrid polymer fiber cementitious composites are lightweight materials and have improved mechanical, damping, and thermal properties. (SATHISHKUMAR; NAVEEN; SATHEESHKUMAR, 2014)

Hybrid fiber is used to improve the workability and control the early-age cracking in fresh concrete. It increases the toughness of the concrete by cracking bridging and reduction in 
DOI: 10.14807/ijmp.v11i3.1081

crack tip opening displacements CTOD. Hence, optimum performance can be obtained by mixing of different fibers. (YAO; LI; WU, 2003, AFROUGHSABET; BIOLZI; MONTEIRO, 2018)

Bentur and Mindess suggested the use of strong and stiff fiber for increasing first crack stress and ultimate strength. The flexible and ductile fiber is used for improving toughness and post-cracking strain capacity.

This research is being carried out to explore combinations of feasible hybrids to obtain desired properties. The research of Sivakumar A, Santhanam M. on hybrid fiber showed that only one combination of polypropylene fiber $(0.12 \%)$ with steel fiber $(0.88 \%)$ performed better than mono steel fiber. All other combinations showed a decrease in flexural toughness when nonmetallic fiber was increased. Glass fiber showed poor toughness performance because of its short length and reduced bond with the matrix. Because of the lower density of nonmetallic fiber, a high amount of fiber in the mix may be the reason for higher strength. However, they cannot sustain high crack width and has more reduced post-peak performance than steel.

It was concluded in a study that only a small percent of nonmetallic fiber, with steel fiber, can show similar toughness to mono steel fiber. Polymeric fibers, e.g., polypropylene and polyvinyl, can offer excellent early crack resistance. (SIVAKUMAR; SANTHANAM, 2007)

In an investigation on polypropylene fiber, showed that $1.5 \mathrm{~kg} / \mathrm{m}^{3}$ performed better in terms of compressive strength, permeability and electrical resistivity (KAKOOEI et al., 2012).

The carbon fiber of different sizes increases the bearing capacity to crack, ultimate stress and Young's modulus of fiber cementitious composite. (HOSSAIN; AWAL, 2011)

Carried out a study on steel cord and synthetic fiber, it was found that hybrid cementitious composites performed better by showing higher strength and ductility in flexure. Multiple cracks and pseudo hardening strain under uniaxial tension confirmed hybrid fiber sufficiency as high-performance fiber (KAWAMATA; MIHASHI; FUKUYAMA, 2003).

Incorporation of hybrid fiber in concretes increases ductility, toughness, energy absorption capacity, and durability performance in comparison to single fiber reinforced concrete (PAKRAVAN; LATIFI; JAMSHIDI, 2017).

Use of hybrid fibers instead of mono-fiber can improve mechanical strength and performance synergy of FRC (BANTHIA et al., 2014). 
DOI: 10.14807/ijmp.v11i3.1081

Yao W, Li J, and Wu K conducted a study, for constant fiber volume (0.5\%), the hybrid fiber composites; Polypropylene carbon hybrid composite, polypropylene steel hybrid fiber composite, and steel carbon hybrid composites. Only carbon and steel showed high strength.

According to the author, similar modulus and synergistic interaction can be the reason. (YAO; LI; WU, 2003). Pakravan HR, Latifi M, and Jamshidi M showed that hybrid fiber reinforcement showed improved toughness, energy absorption, ductility, and durability (PAKRAVAN; LATIFI; JAMSHIDI, 2017).

Mobasher B and Li CY investigated the tensile and flexural strength of carbon and alumina whisker and polypropylene fiber, significant strength increase was observed for whiskers, but ultimate strength and post-peak toughening was not much affected by whiskers due to inability to bridge macrocracks. Fracture toughness was increased by PP fibers. Hence hybrid composite performed better in terms of strength and toughness. (MOBASHER; LI, 1996)

Silva ER, Coelho J, Bordado JC (2013) found that the hybrid polyethylene and polypropylene fiber composites showed higher mechanical strength for $24 \mathrm{~mm}$ long fibers and 2.9\% fiber. The strong fiber mechanical interlocking enhanced mechanical strength properties. The post cracking ductility was improved for the composite. (SILVA; COELHO; BORDADO, 2013)

Fibers are used in FRC depending on their application. For pipes and roofing asbestos fiber is used. For precast panels, glass fibers may be used. For pavements, dams, and shotcretes, steel fibers are preferable. Polypropylene fibers are used as a secondary reinforcement to control plastic shrinkage cracking. Vegetable fibers are used in low-cost building materials.

In this investigation, single fiber composites are compared with each other, and their hybrid combinations are studied to find out the feasible combinations. The main aim of the study is to compare the single and hybrid fiber cementitious composites (FRC) in terms of strength, toughness, workability, and cost.

Among different types of fibers used in this study, i.e., plain steel, carbon, polypropylene and glass fiber, Steel and carbon fibers are relatively expensive while polypropylene and glass fibers are cheap. The purpose of the study is not to attain high strengths but is to understand the roles of type of fiber (single and hybrid) in deciding the mix design to obtain desired properties at an affordable cost. 
DOI: 10.14807/ijmp.v11i3.1081

The total volume of fiber was kept $1.25 \%$ of concrete. Polycarboxylic based superplasticizer $1.5 \%$ of cement weight, was used with a water-cement ratio of 0.5 . SBR latex $4 \%$ was added to compensate for the loss of workability due to the addition of fibers and to provide protection against deterioration of fibers. SBR modified concrete decreases the permeability and ingress of water and ions in concretes. SBR increase the adhesive quality of concretes and mortars (beneficial for pullout failure).

\subsection{Fracture Mechanics Approach}

In plain concrete, strain-softening does not occur; this behavior is close to linear elastic fracture mechanics. It results in the accumulation of strain energy in the material. The fracture process zone in front of these longitudinal splitting bond cracks would be small, and all energy is available for fracture initiation. As soon as the strain energy becomes greater than fracture energy required, the cracks initiate at the interfacial transition zones. There is a zone of energy dissipation in front of this crack.

In the case of brittle materials like concrete, this zone is minimal, and all the available energy is used in the crack propagation.

It results in a reduction in strain energy; however, if the accumulated energy is sufficient enough to cover the fracture energy required for crack propagation, the crack starts moving. It results in a further decrease in strain energy. However as a fiber stops this crack then the stress is transferred to the fiber if the fiber is strong enough to carry that stress, like steel or carbon fiber, then crack stops propagating and fracture toughness of the concrete increases significantly. Moreover, the strain-softening behavior is also introduced that further results in an increase in fracture toughness.

After Eq. (1) to Eq (3) gave this behavior of High Strength Concrete (DAVID; BROEK, 1979); ACI 446.1 R-91, 1991) as shown in Figure 1 (BROEK, 1974). 
DOI: $10.14807 /$ ijmp.v11i3.1081

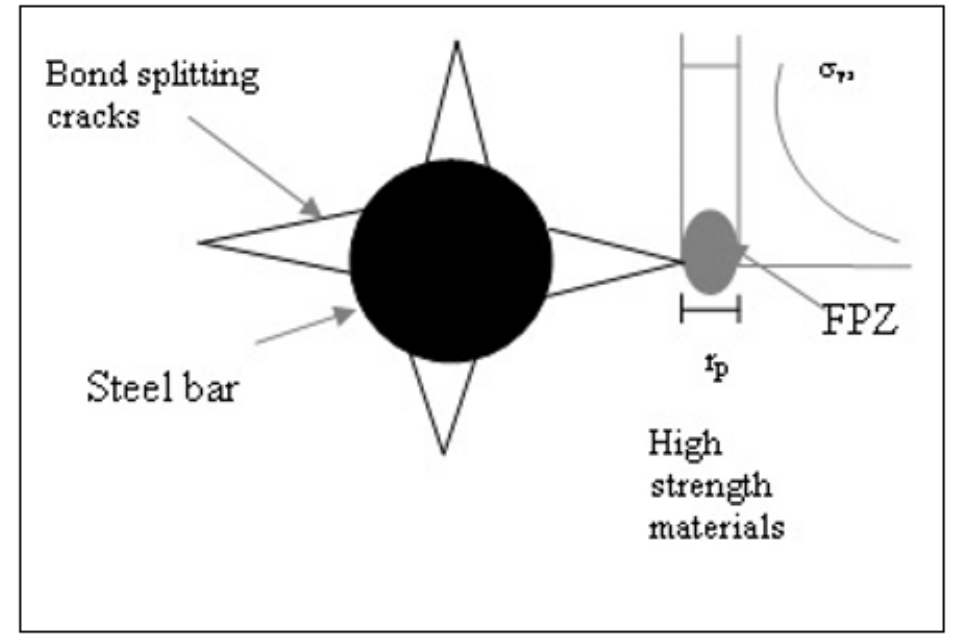

Figure 1: Fracture process zone in high strength concrete pullout samples (Kafeel, 2009)

$\sigma_{\mathrm{ys}}=\frac{\operatorname{ki}}{\sqrt{2 \sec p}}$

$\mathrm{r}_{\mathrm{p}}=\frac{K i 2}{2 \pi \sigma_{\mathrm{ys}}}$

$\mathrm{r}_{\mathrm{p}} \quad \alpha \frac{\mathrm{Ki2}}{\sigma_{y s} 2}$

where

$\sigma_{\mathrm{ys}}=$ Yield strength of the material

$r_{p}=$ Size of the fracture process zone

$\mathrm{K}_{\mathrm{I}}=$ Stress intensity factor

However, in case of FRHSC the presence of steel fibers, that are bridging the cracks, FRHSC needs more energy to pull out these fibers out of the matrix. Hence increased bond energy is required for the formation and propagation of bond splitting cracks, and this results in improved bond strength.

\section{MATERIALS AND METHODOLOGY}

\subsection{Materials}

Ordinary Portland cement (ASTMC150 Type1), Lawrencepur sand (fineness modulus 2.4), and polycarboxylic based superplasticizer (Chemrite sp303, conforming to ASTM C 494 Types A, D \& F) were used in the mix preparation. Styrene-Butadiene Rubber (SBR) latex (Imporient Chemicals) was added to improve durability, adhesive quality, and workability of 


\section{INDEPENDENT JOURNAL OF MANAGEMENT \& PRODUCTION (IJM\&P)}

http://www.ijmp.jor.br

v. 11, n. 3, May-June 2020

ISSN: 2236-269X

DOI: 10.14807/ijmp.v11i3.1081

fiber cementitious composites. Polypropylene fiber (450MPa tensile strength, i.e., low strength), glass fiber, steel fiber, and carbon fiber (TC36S12K) were used for reinforcing the cementitious composite (See Figure 2). The physical and mechanical properties of cement and fibers are given in Table 2 and Table 2.
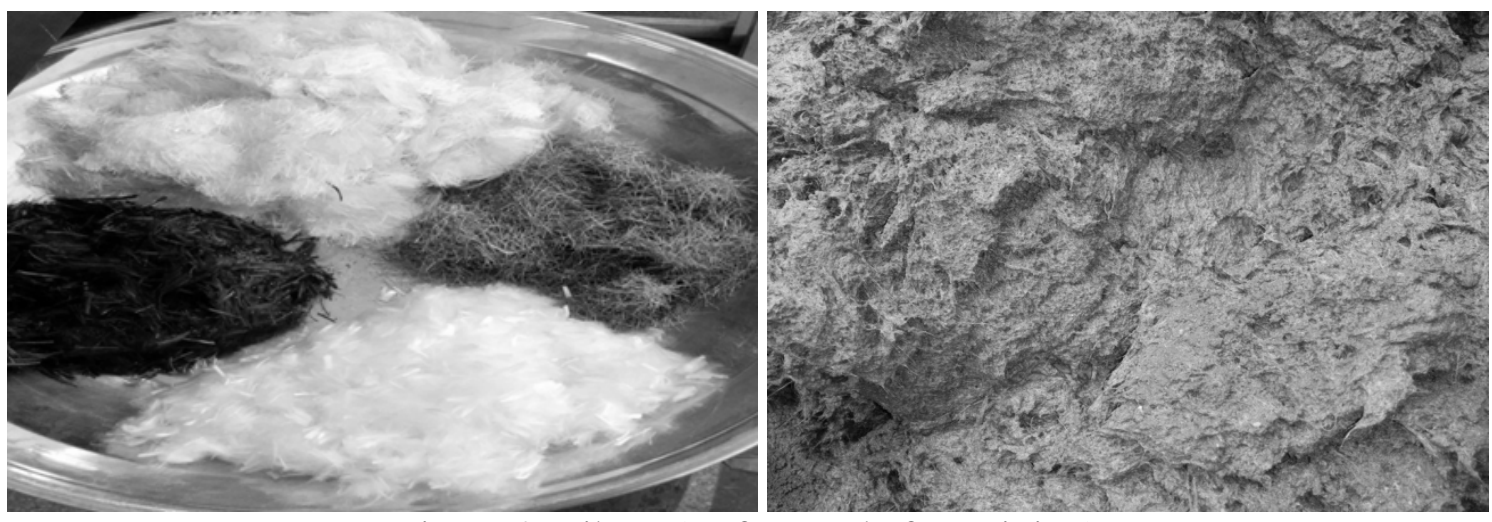

Figure 2: Fibers (Before and after mixing)

Table 1: Properties of Cement and Sand

\begin{tabular}{|c|c|}
\hline \multicolumn{2}{|c|}{ Physical Properties of Cement } \\
\hline Standard consistency & 30 \\
\hline Initial setting time & $1 \mathrm{hr} 31 \mathrm{~min}$ \\
\hline Final setting time & $3 \mathrm{hr} 32 \mathrm{~min}$ \\
\hline Color & Grey \\
\hline Specific gravity & 3.15 \\
\hline Blaine $\mathrm{cm}^{2} / \mathrm{g}$ & 3090 \\
\hline \multicolumn{2}{|c|}{ Chemical Properties of Cement } \\
\hline $\mathrm{SiO}_{2} \%$ & 20.25 \\
\hline $\mathrm{Al}_{2} \mathrm{O}_{3} \%$ & 5.05 \\
\hline $\mathrm{Fe}_{2} \mathrm{O}_{3} \%$ & 3.13 \\
\hline $\mathrm{CaO} \%$ & 62.13 \\
\hline $\mathrm{MgO} \%$ & 2.29 \\
\hline $\mathrm{K}_{2} \mathrm{O} \%$ & 0.74 \\
\hline $\mathrm{Na}_{2} \mathrm{O} \%$ & 0.24 \\
\hline $\mathrm{SO}_{3} \%$ & 2.57 \\
\hline LOI \% & 4.42 \\
\hline \multicolumn{2}{|c|}{ Physical Properties of Sand } \\
\hline Fineness modulus & 2.7 \\
\hline Max. aggregate size & $4.75 \mathrm{~mm}$ \\
\hline Specific gravity & 2.625 \\
\hline
\end{tabular}

Table 2: Physical Properties Of Fibers

\begin{tabular}{|l|l|l|l|l|}
\hline \multicolumn{1}{|c|}{ Physical properties } & $\begin{array}{c}\text { Polypropylene } \\
\text { fiber }\end{array}$ & Glass fiber & $\begin{array}{c}\text { Carbon } \\
\text { fiber }\end{array}$ & \multicolumn{1}{c|}{$\begin{array}{c}\text { Steel } \\
\text { Fiber }\end{array}$} \\
\hline Length (mm) & $12 \mathrm{~mm}$ & 20 & 25 & 25 \\
\hline Diameter (mm) & $7 \mathrm{um}$ & 0.15 & 7 um & 0.27 \\
\hline Aspect ratio & 1715 & 133 & 3571 & 93 \\
\hline Density(g/cm3) & 0.9 & 2.6 & 1.81 & 7.8 \\
\hline Tensile Strength(MPa) & $300-450$ & $1900-2500$ & 4900 & $500-1500$ \\
\hline Elastic modulus (GPa) & ---- & 70 & 250 & $190-210$ \\
\hline Crack Elongation (\%) & $15 \%$ & $2 \%$ & $1-2 \%$ & $0.5-3.5 \%$ \\
\hline
\end{tabular}

\section{METHODOLOGY}


INDEPENDENT JOURNAL OF MANAGEMENT \& PRODUCTION (IJM\&P)

http://www.ijmp.jor.br

v. 11, n. 3, May-June 2020

ISSN: 2236-269X

DOI: 10.14807/ijmp.v11i3.1081

\subsection{Mix Proportion}

All fibers (especially polypropylene and Carbon fiber) were scattered by hand before mixing. Fibers were added during dry mixing, and then superplasticizer (1.5\% of cement weight), water (w/c 0.5), and SBR latex (4\% of cement weight) were added one by one.

Fourteen batches were prepared. The total volumetric fraction of fiber was kept $1.25 \%$ for all composites. The FRC compositions are given in Table 3.

Table 3: Volumetric Fraction of Fibers

\begin{tabular}{|c|r|r|r|r|}
\hline \multirow{2}{*}{ Mixture ID } & \multicolumn{5}{|c|}{ Volumetric Fraction of Fibers (\%) } \\
\hline & & & & \\
& Polypropylene fiber & Glass fiber & Steel fiber & Carbon fiber \\
\hline P & 1.25 & & & \\
\hline G & & 1.25 & & \\
\hline S & & & 1.25 & 1.25 \\
\hline C & 0.625 & 0.625 & & 0.625 \\
\hline PG & & & 0.625 & 0.625 \\
\hline SC & 0.625 & & & 0.417 \\
\hline PC & 0.5 & 0.5 & 0.25 & 0.31 \\
\hline PGS & 0.417 & 0.417 & & 0.32 \\
\hline PGC & 0.31 & 0.31 & 0.31 & 0.06 \\
\hline PGSC1 & 0.64 & 0.22 & 0.07 & 0.1 \\
\hline PGSC2 & 0.525 & 0.525 & 0.06 & \\
\hline PGSC3 & 0.56 & 0.57 & 0.06 & \\
\hline PGSC4 & & & &
\end{tabular}

\subsection{Test Methods}

Each FRC mix was cast into four 4" cubes for the compressive strength test (as shown in Figure 3), four prisms (4"x4"x20") for flexure test and four (4"x8") cylinders for the split tensile test. The slump was noted for each mix. Samples were tested for the strengths on the 28th day of casting. The compression test, flexural strength, and the split tensile test were conducted.
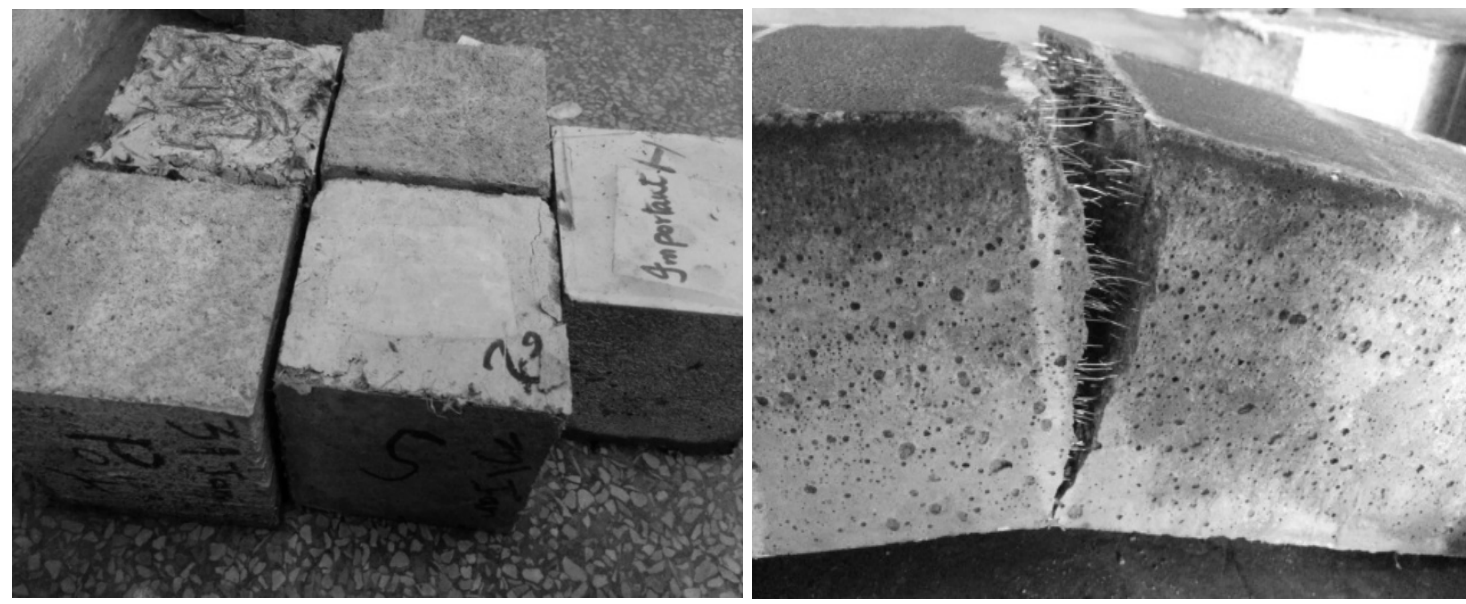

Figure 3: Fiber-Reinforced Composites 
INDEPENDENT JOURNAL OF MANAGEMENT \& PRODUCTION (IJM\&P)

http://www.ijmp.jor.br

v. 11, n. 3, May-June 2020

ISSN: 2236-269X

DOI: 10.14807/ijmp.v11i3.1081

\section{RESULTS AND DISCUSSIONS:}

Table 4 provides a general view of the results obtained.

Table 4: Properties Of FRC

\begin{tabular}{|l|c|r|r|r|r|}
\hline $\begin{array}{c}\text { Mixture } \\
\text { ID }\end{array}$ & $\begin{array}{c}\text { Flexural } \\
\text { strength }\end{array}$ & \multicolumn{1}{c|}{$\begin{array}{c}\text { Tensile } \\
\text { strength }\end{array}$} & $\begin{array}{c}\text { Compressive } \\
\text { strength }\end{array}$ & Toughness & Workability \\
\hline & $\mathbf{( M P a )}$ & \multicolumn{1}{c|}{$\mathbf{( M P a )}$} & \multicolumn{1}{c|}{$\mathbf{( M P a )}$} & \multicolumn{1}{c|}{ Joule } & \multicolumn{1}{c|}{ Slump (in) } \\
\hline P & 2.60 & 2.57 & 25.2 & 17.26 & 6 \\
\hline G & 2.90 & 2.87 & 31.2 & 5.14 & 2.5 \\
\hline S & 6.31 & 4.44 & 39.1 & 58.06 & 9 \\
\hline C & 7.85 & 5.58 & 41.4 & 21.10 & 1.25 \\
\hline PG & 4.06 & 2.72 & 28.8 & 7.07 & 4.125 \\
\hline SC & 4.58 & 4.54 & 36 & 18.90 & 5 \\
\hline PC & 3.95 & 3.93 & 32.4 & 12.87 & 4.75 \\
\hline PGS & 3.86 & 3.21 & 32.4 & 14.12 & 4.5 \\
\hline PGC & 3.82 & 3.37 & 31.2 & 8.35 & 3.75 \\
\hline PGSC1 & 4.46 & 2.72 & 24 & 15.58 & 6.5 \\
\hline PGSC2 & 3.89 & 1.97 & 21.6 & 9.78 & 6.875 \\
\hline PGSC3 & 4.06 & 2.57 & 22.8 & 8.73 & 6.5 \\
\hline PGSC4 & 3.85 & 2.42 & 21.6 & 10.56 & 5.125 \\
\hline
\end{tabular}

\section{Compressive Strength}

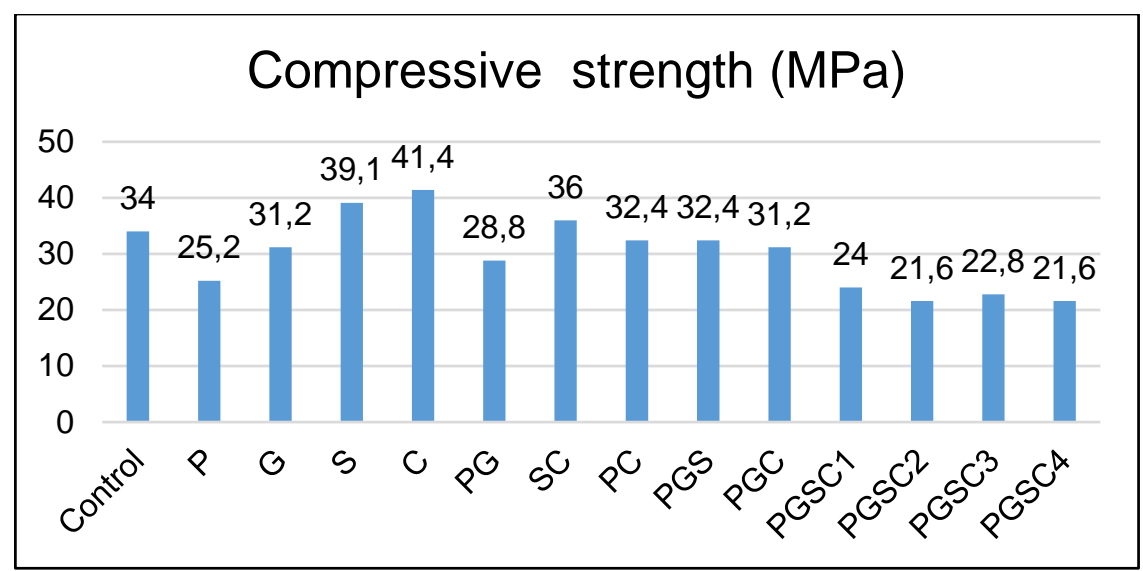

Figure 4: Compressive Strengths of Single and Hybrid FRC

Table 4 and Figure 4 show that at constant volume of fiber and water-cement ratio, the polypropylene fiber showed minimum compressive strength and Carbon fiber showed the maximum. The order of compressive strengths was as following:

$$
\text { Polypropylene }<\text { Glass }<\text { Steel }<\text { Carbon }
$$

When fibers were mixed, and hybrid FRC was prepared, then all tetra combinations were unsuccessful in terms of compressive strength, as they showed much lower strengths than single fiber composites. Trihybrid did not show good results too. In bi-hybrid composites, Polypropylene glass and polypropylene carbon hybrid were found okay for use, but steel carbon composites showed lower strength than its single fiber composites. The loss in strength may be due to completely different fiber types and incompatibility of fibers. 


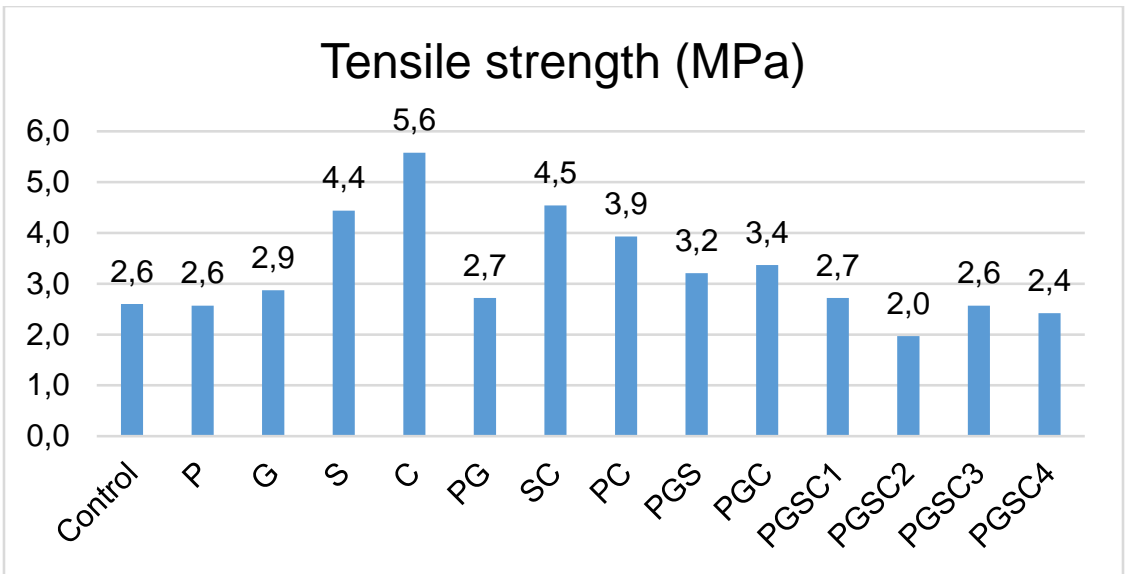

Figure 5:Tensile Strengths of Single and Hybrid FRC

Table 4 and Figure 5 reveal that at constant volume of fiber and water-cement ratio, the polypropylene fiber showed minimum tensile strength and Carbon fiber showed maximum. The order of tensile strengths was as following:

$$
\text { Polypropylene }<\text { Glass }<\text { Steel }<\text { Carbon }
$$

Polypropylene fiber used in this study had lower tensile strength as compared to other types of polypropylene fibers available in the market.

All tetra combinations were unsuccessful in terms of tensile strength, as they showed much lower strengths than single fiber composites. Tri-hybrid did not show good results too. In bi-hybrid composites, Polypropylene glass and polypropylene carbon hybrid were found okay for use, but steel carbon composites showed lower strength than its single fiber composites. The loss in strength may be due to incompatibility of fiber types.

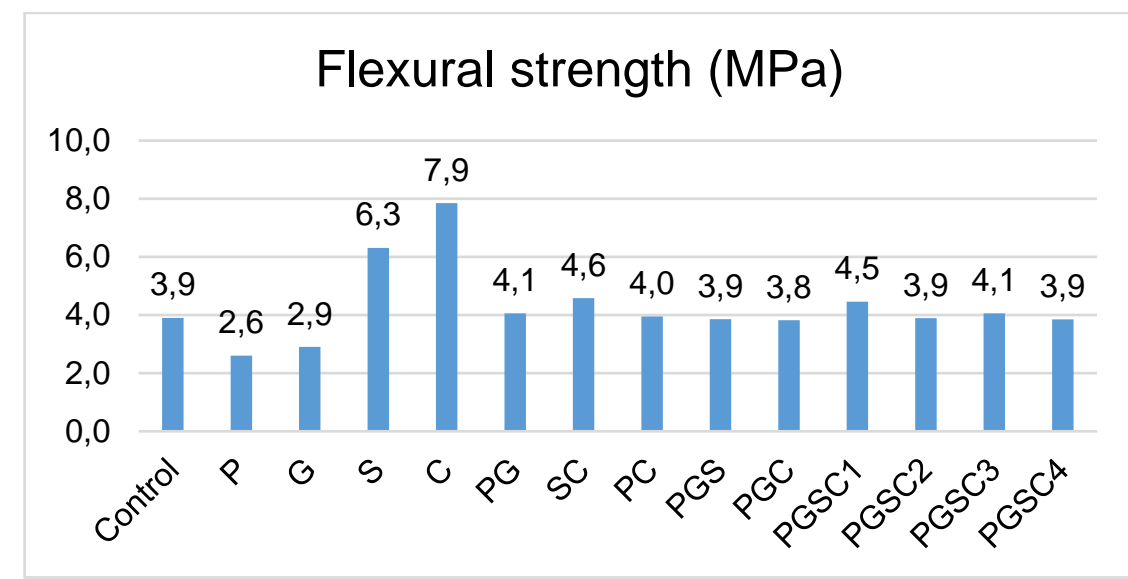

Figure 6: Flexural Strengths of Single and Hybrid FRC

Table 4 and Figure 6 refers that the order of flexural strengths was as follows:

$$
\text { Polypropylene }<\text { Glass }<\text { Steel }<\text { Carbon }
$$


DOI: 10.14807/ijmp.v11i3.1081

At a constant volume of fiber and water-cement ratio, the polypropylene fiber showed minimum flexural strength, and Carbon fiber showed the maximum.

In Bi-hybrid combinations, only Poly-Glass performed better. Steel-Carbon showed lower flexural strength than single FRCs. Poly-Carbon was just acceptable.

Tri-hybrid composites did not show poor results. They were just okay for use. Tetrahybrid composites performed least as the average strengths of mixed single fiber composites were not attained in tetra-hybrid composites.

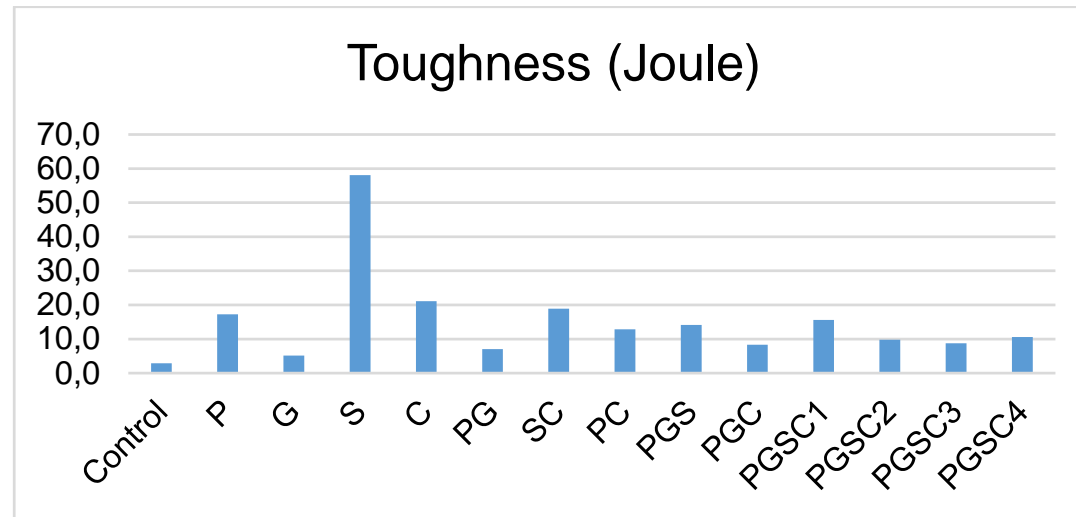

Figure 7: Comparative Toughness of Single And Hybrid FRC

Table 5, Figure 7, and Figure 8 refer to comparative toughness of FRC. The toughness of composites was maximum for steel fiber, followed by carbon, polypropylene, and glass fiber. Steel fiber composite is the toughest. Polypropylene showed good toughness at low cost, hence was a favorable composite. Glass fiber showed the least toughness. Hybrid fiber composite did not show better toughness than single fiber composites.

Table 5: Toughness Of FRC

\begin{tabular}{|l|l|l|l|}
\hline Fiber Composite & Total toughness (Joule) & Post crack toughness (Joule) & Pre-crack toughness \\
\hline P & 17.26 & 15.61 & 1.65 \\
\hline G & 5.14 & 1.64 & 3.51 \\
\hline S & 58.06 & 52.88 & 5.19 \\
\hline C & 21.10 & 7.15 & 13.95 \\
\hline PG & 7.07 & 4.10 & 2.97 \\
\hline SC & 18.90 & 13.47 & 5.43 \\
\hline PC & 12.87 & 9.90 & 2.98 \\
\hline PGC & 8.35 & 4.53 & 3.81 \\
\hline PGS & 14.12 & 11.89 & 2.23 \\
\hline PGSC1 & 15.58 & 10.59 & 5.00 \\
\hline PGSC2 & 10.56 & 6.20 & 4.36 \\
\hline PGSC3 & 9.78 & 6.08 & 3.70 \\
\hline PGSC4 & 8.73 & 5.94 & 2.79 \\
\hline
\end{tabular}


ISSN: 2236-269X

DOI: 10.14807/ijmp.v11i3.1081
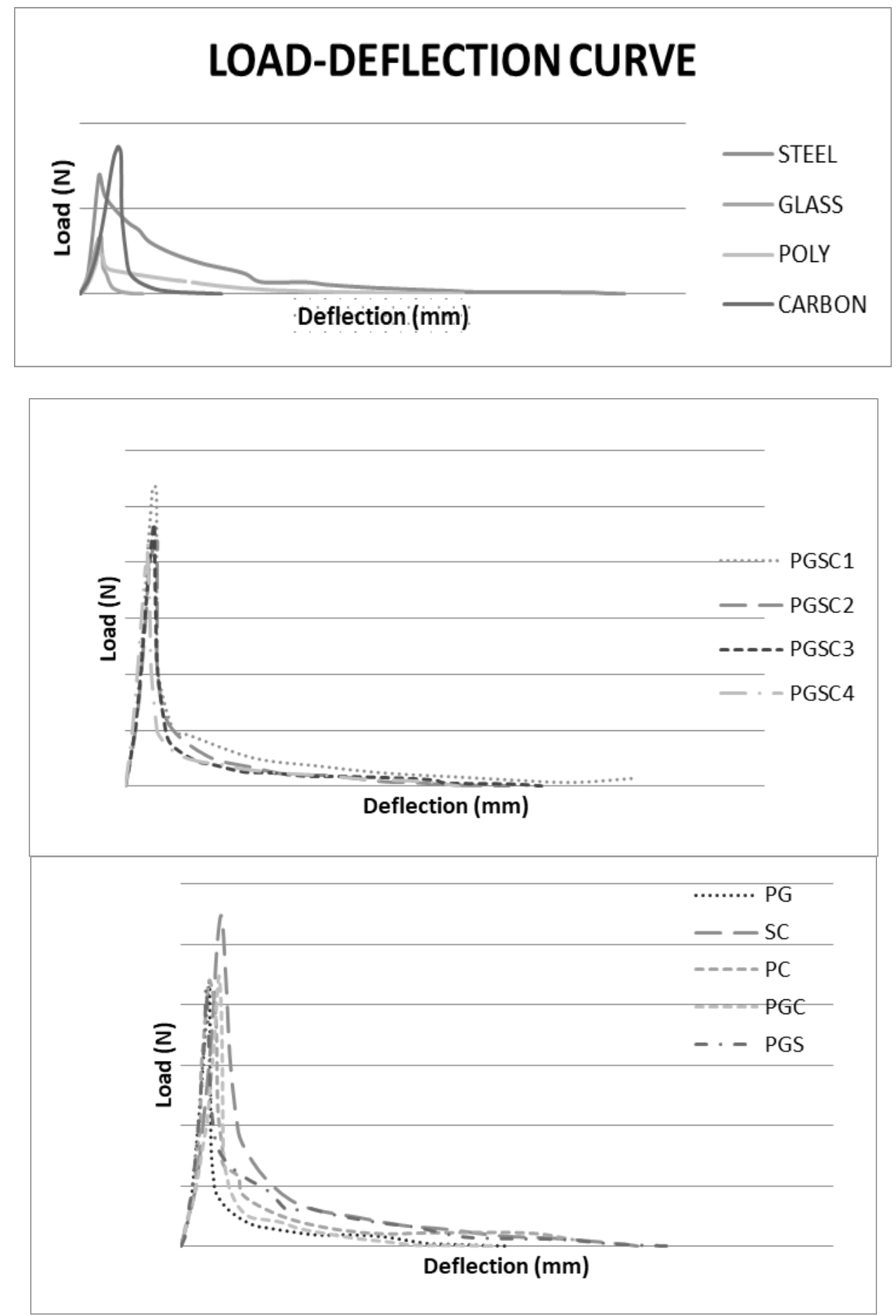

Figure 8: Comparative Load Deflection Curves of Single and Hybrid FRC 


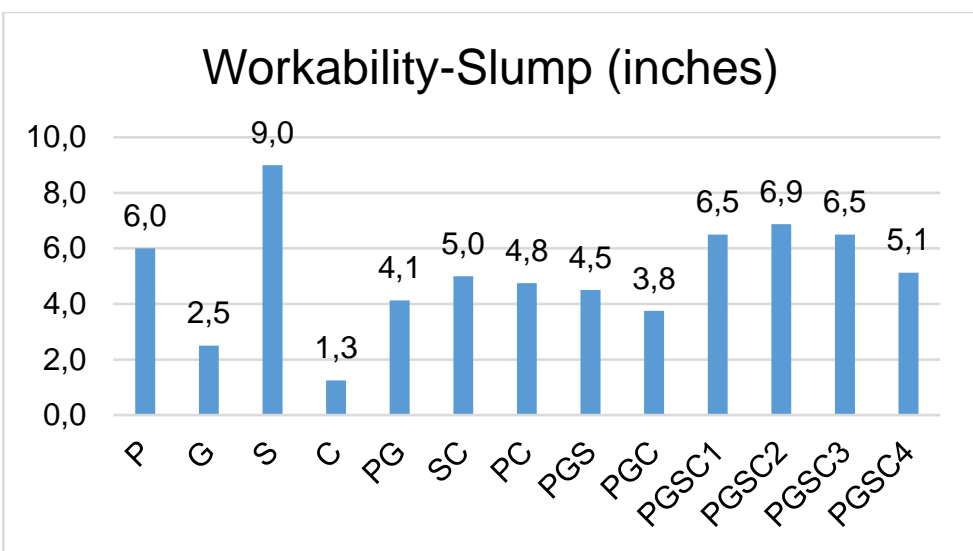

Figure 9: Slumps of Single and Hybrid FRC

In terms of workability, i.e., slump value (Figure 9), Carbon fiber was the least workable, and the steel fiber was the most workable. Polypropylene fiber was more workable than glass fiber. Hybrid fibers showed better workability in all cases.

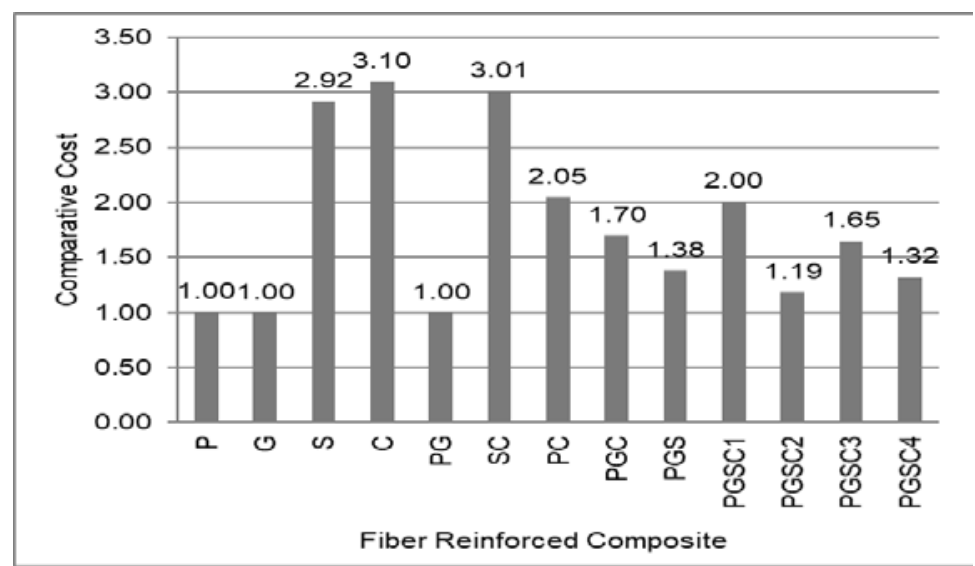

Figure 10: Comparative Costs of Single and Hybrid FRC

Cost analysis (Figure 10) showed that in Pakistan, polypropylene and glass fiber composites are almost of equal price for the constant volume of the concrete composite. Carbon fiber is slightly expensive than steel. Carbon and steel fibers are 3 times costlier than polypropylene and glass fiber.

The comparison of the overall results and the suitability of the combination used in terms of its properties and cost is determined.

\section{CONCLUSIONS}

The following conclusions are made for the single and hybrid compositions of fibers and SBR latex in cement composites. The plain steel fiber, glass fiber, low strength polypropylene fiber, and carbon fiber were used in the investigation. 
DOI: 10.14807/ijmp.v11i3.1081

1) Carbon fiber showed the highest strengths in terms of compression, tension, and flexure in FRC, followed by steel fiber. Polypropylene fiber showed the lowest strengths.

2) Steel fiber showed the highest toughness, followed by carbon fiber in FRC.

3) Polypropylene fiber composite was low cost, low strength, but tough and workable.

4) Glass fiber composite was slightly stronger and workable, but less tough than polypropylene composite.

5) Carbon fiber was least workable while steel was the most workable (in terms of slump value).

6) Carbon fiber and steel fiber were expensive, while polypropylene and glass fiber were cheap.

7) In terms of strength, generally Bi-hybrid composites showed better results, almost average of their single fiber composites except for steel-carbon composite, the polyglass composite was successful while poly-carbon composite was satisfactory for tensile and flexural capacities.

8) Tri-hybrid composites showed generally poor strength results as compared to two of its single fiber composites. Thus tri-hybrid composites, i.e., poly-glass-carbon and polyglass-steel were not satisfactory for use.

9) Tetra-hybrid composites showed poor performance in terms of strengths.

10) The poor performance of tri and tetra hybrid fiber may be linked to the incompatibility of more fibers to be used together due to their different properties.

\section{ACKNOWLEDGEMENT}

The research is supported by the Faculty Research Project Grant (No. ORIC/101ASRB/4454), “Effect of hybrid fibers on mechanical properties of fiber reinforced cementitious composites” by University of Engineering and Technology Lahore.

\section{REFERENCES}

AFROUGHSABET, V.; BIOLZI, L.; MONTEIRO, P. J. (2018) The effect of steel and polypropylene fibers on the chloride diffusivity and drying shrinkage of high-strength concrete. Composites Part B: Engineering, v. 139, p.84-96.

ACI 446.1 R-91 (1991) Fracture mechanics of concrete: concepts, models and determination of material properties, Reported by ACI Committee 446, Fracture Mechanics, (Reapproved 1999).

AHMED, K. (2009) Bond strength of ultra high strength concrete at intersection of beams (Doctoral dissertation, University of Engineering \& Technology, Lahore). 
BADR, A.; ASHOUR, A. F.; PLATTEN, A. K. (2006) Statistical variations in impact resistance of polypropylene fiber-reinforced concrete. International Journal of Impact Engineering, v. 32, n. 11, p. 1907-1920.

BANTHIA, N.; MAJDZADEH, F.; WU, J.; BINDIGANAVILE, V. (2014) Fiber synergy in Hybrid Fiber Reinforced Concrete (HyFRC) in flexure and direct shear. Cement and Concrete Composites, v. 48, p. 91-97.

BENTUR, A.; MINDESS, S. (2006) Fibre reinforced cementitious composites. Crc Press.

BROEK, D. (1974) Elementary engineering fracture mechanics, $1^{\text {st }}$ edition, ISBN: 90286 0304 2, Noordhoff International Publishing Lyden, 1974.

HOSSAIN, M. Z.; AWAL, A. A. (2011) Flexural response of hybrid carbon fiber thin cement composites. Construction and Building Materials, v. 25, n. 2, p. 670-677.

KAKOOEI, S.; AKIL, H. M.; JAMSHIDI, M.; ROUHI, J. (2012) The effects of polypropylene fibers on the properties of reinforced concrete structures. Construction and Building Materials, v. 27, n. 1, p. 73-77.

KAWAMATA, A.; MIHASHI, H.; FUKUYAMA, H. (2003) Properties of hybrid fiber reinforced cement-based composites. Journal of advanced concrete Technology, v. 1, n. 3, p. 283-290.

PAKRAVAN, H. R.; LATIFI, M.; JAMSHIDI, M. (2017) Hybrid short fiber reinforcement system in concrete: A review. Construction and building materials, v. 142, p. 280-294.

SIDDIQI, Z. A.; HAMEED, R.; SALEEM, M.; KHAN, Q. S.; QAZI, J. A. (2013)

Determination of Compressive Strength And Water Absorption of Styrene Butadiene Rubber (SBR) Latex Modified Concrete. Pakistan Journal of Science, v. 65, n. 1, p. 124.

SATHISHKUMAR, T. P.; NAVEEN, J. A.; SATHEESHKUMAR, S. (2014) Hybrid fiber reinforced polymer composites-a review. Journal of Reinforced Plastics and Composites, v. 33, n. 5, p. 454-471.

SILVA, E. R.; COELHO, J. F. J.; BORDADO, J. C. (2013) Hybrid polyethylene/polypropylene blended fiber-reinforced cement composite. Journal of Composite Materials, v. 47, n. 25, p. 3131-3141.

SIVAKUMAR, A.; SANTHANAM, M. (2007) Mechanical properties of high strength concrete reinforced with metallic and non-metallic fibres. Cement and Concrete Composites, v. 29, n. 8, p. 603-608.

SONI, K.; JOSHI, Y. P. (2014) Performance analysis of styrene butadiene rubber-latex on cement concrete mixes. Journal of Engineering Research and Applications, v. 3, n. 1, p. 838-44.

WANG, R.; LACKNER, R.; WANG, P. M. (2011) Effect of styrene-butadiene rubber latex on mechanical properties of cementitious materials highlighted by means of nanoindentation. Strain, v. 47, n. 2, p. 117-126.

YAO, W.; LI, J.; WU, K. (2003) Mechanical properties of hybrid fiber-reinforced concrete at low fiber volume fraction. Cement and concrete research, v. 33, n. 1, p. 27-30.

ZHANG, C.; CAO, M. (2014) Fiber synergy in multi-scale fiber-reinforced cementitious composites. Journal of Reinforced Plastics and Composites, v. 33, n. 9, p. 862-874. 